\title{
SUBSEPSIS ALLERGICA WISSLER-FANCONI, ANTICAMERA COLAGENOZELOR LA COPII
}

\author{
Bauer Adalbert ${ }^{1}$ \\ Imedic primar pediatru, doctor în medicină
}

\section{Title: Subsepsis allergica Wissler-Fanconi, the waiting room for collagenosis at childrens}

Abstract: I present a disease with allergic constituent, whose clinical presentation include discontinuous fever on a long period of months, inconstant exanthema, with promptly demise at corticotherapy, but who many times is followed by a collagen group disease, or by miscellanous simptomatology of these group.

Key words: collagenosis, childrens, Wissler-Fanconi syndrom, corticotherapy.

Rezumat: prezint o afecțiune cu caracter alergic, al cărei tablou clinic cuprinde febră cu caracter intermitent cu durată de luni de zile, exanteme variabile, și care cedează prompt la corticoterapie, dar care de multe ori este urmată în timp de o boală din grupul colagenozelor, sau de o simptomatologie intricată a acestora.

Cuvinte cheie: colagenoze, copii, sindrom Wissler-Fanconi, corticoterapie.

\section{Baze raționale}

În tratatul de pediatrie a lui Fanconi-Walgreen din 1956, boala Wissler-Fanconi -subsepsis allergica- este descrisă ca o boală reactivă cu caracter net alergic; tabloul clinic cuprinde febră cu caracter intermitent cu durată de luni de zile, exanteme variabile maculoase, uneori urticariene, care cedează prompt la corticoterapie. Ea trece uneori în poliartrită evolutivă cronică. Din această entitate, mai puțin caracteristică din punct de vedere clinic, se pot dezvolta forme clinice diferite de colagenoze la copil [2]. Literatura germană a acceptat inițial doar o singură formă de colgenoză care urmează sindromului Wissler-Fanconi, respectiv atrita reumatoidă juvenilă.

Recunoașterea legăturii dintre sindromul Wissler-Fanconi cu o afecțiune din grupul colagenozelor, a atras atenția asupra imnportanței identificării acestuia în antecedente patologice personale a copilului, în special pentru lupusul eritematos diseminat acut (LED), dermatomiozită, periarterita nodoasă, poliartrita cronică evolutivă, purpura Schonlein-Henoch, arterita Wagener cu celule gigante, sindromul Takayasu, dar și pentru formele intricate, greu încadrabile, ale colagenozelor.

În ceea ce privește etiologia și patogeneza colagenozelor, decenii după formularea lui Klemperer, aproape nimic nu s-a schimbat: afecțiunea este ubicuitară în țesuturi și viscere, având un debut polimorf, cu numeroase forme clinice intricate, sau prin succesiunea unor entități diferite de colagenoze.

Denumirea de colagenoză a fost creată de Klemperer în 1941, dar încă din 1929 Klinge a recunoscut că degenerescența fibrinoidă a țesutului conjunctiv prin mecanism alergic reprezintă alterarea tisulară cea mai caracteristică. Sistemele de organe care conțin mult țesut conjunctiv și sunt bogate în fibre de colagen, sunt cel mai frecvent afectate: sistemul cardiovascular, musculatura, pielea, fiind de fapt o boală primitivă de autoagresiune. Descoperirea celulei lupice Heller-Zimmerman de tip B reprezintă elementul pentru identificarea afecțiunii.

Entitățile încadrabile aici nu debutează decât rar cu simptomatologie clasică, predominând forme intricate, forme de trecere, fapt care pune în dificultate diagnosticul. Aforismul academicianului 
profesor doctor Gheorghe Goldiș rămâne valabil și azi: „dacă nu știi la ce să te gândești în fața unui caz clinic greu descifrabil, gândește-te și la o colagenoză”.

Spitalul Clinic Fundeni, București, a prezentat statistic cazuistica proprie în ordinea frecvenței: atrită reumatoidă, lupus eritematos diseminat acut, purpura Schonlein-Henoch, dematomiozita, sclerodermia, periarterita nodoasă.

La un moment dat grupul colagenozelor a devenit „un coș de gunoi”, în care au fost incluse o mulțime de afecțiuni neîncadrabile nosologic. În ultimele două decenii au fost stabilite multe aspecte de delimitare a cadrelor nosologice, dar cu rezultate modeste în privința etiologiei și patogenezei afecțiunii.

\section{Motivarea prezentării cazurilor}

-sunt două cazuri de colagenoze, cu debut prin sindrom Wissler-Fanconi.

-importanța succesiunii cronologice a aspectelor patogenetice și clinice, până la conturarea clară a tabloului clinic, de colagenoză încadrabilă: subsepsis allergica-reumatism poliarticular acut-atrită reumatoidă-lupus eritemtos diseminat acut și respectiv subsepsis allergica-colită ulceroasă-atrita reumatoidă.

\section{Prezentarea cazurilor}

Cazul nr 1: copil de șapte ani din Satu-Mare, s-a prezentat la serviciul nostru pentru încadrarea nosologică a unei suferințe îndelungate, de natură aparent reumatismală, motiv pentru care a fost internat de repetate ori în diferite secții de specialitate, și al cărei tablou a fost progresiv, cu modificări cutanate de tip alergic.

De remarcat a fost starea febrilă prelungită, de aproximativ șase săptămâni, cu următoarele caractere: intermitentă, cu stări de subfebrilitate intercalate de două-trei zile, de tip septic

Starea generală a fost relativ bună, fără semne clinice, biologice, bacteriologice, care să pledeze pentru o infecție bacteriană sistemică. La intervale nedeterminabile a fost vizibil un rash cutanat fugace, suprins doar câteva ore.

Diagnosticul de subsepsis allergica a fost un diagnostic retrospectiv, după apariția și a altor simptome clinice evocatoare.

După acest intermezzo febril cu durată neobișnuită, tabloul clinic a fost dominat de manifestări clinice articulare, până la apariția modificărilor cutaneo-mucoase caracterisice pentru un lupus eritematos diseminat acut. Modificările articulare au sugerat în diferite etape de evoluție a bolii, o eventuală formă clinică de colagenoză: debut în urmă cu doi ani, prin artralgii cu caracter migrator, cu localizare la articulațiile mari (genunchi, tibio-tarsiene) și articulațiile mici predominant interfalangiene, însă fără caractere locale de inflamație. Trebuie subliniat faptul că artralgiile au fost însoțite de mialgii puternice, cu caracter predominant matinal, posibil datorate unei miozite interstițiale cu o discretă lezare a fibrelor musculare, prezente de altfel în majoritatea cazurilor formelor comune de LED.

La o internare următoare tabloul clinic se conturează mai net: în afară de febră, copilul prezintă tumefierea articulației genunchiului stâng și a celor tibio-tarsiene bilateral, cu impotență funcțională. Pe baza simptomatologiei precum și a modificărilor biologice, cazul a fost etichetat ca reumatism articular acut la primul puseu, și s-a aplicat un tratament adecvat. Părinții copilului au afirmat că după externare simptomatologia articulară a persistat, manifestându-se prin dureri și tumefierea migratoare, fluxională, a articulațiilor mici și mari, însoțită de subfebrilităţi.

Simptomatologia articulară devine ulterior și mai accentuată prin tumefierea articulațiilor mari și a celor interfalangiene, de aspect fuziform, însoțită de subfebrilități, motive pentru care se decide reinternarea, etichetând cazul ca poliartrită cronică evolutivă, ținând cont în primul rând de artropatia cu durata de peste 3 luni, însă insuficient susținută de argumente biologice. Tentativele de tratament cu antiinflamatoare au eșuat, doar schema clasică de corticoterapie ducând la amendarea simptomatologiei articulare. 
La scurt timp după externare apar manifestările cutaneo-mucoase caracteristice unui LED:

-erupții roseoliforme cu localizare anatomotopografică preponderent la față, retroauricular, latero și retro-cervical, în regiunea pectorală și interscapulară, cu câteva elemente acneiforme.

-exantem fugace, resorbindu-se în 48 de ore, persistând doar modificările cutanate ale feței: elemente congestive roșii-violacee, aspect edematos, cu margini neregulate, discret furfuracee, cu caracter variabil și cu localizare centro-facială, predominant perinazal și periorbital.

-edem al pleoapei superioare, cu câteva elemente teleangiectatice.

-eritem palmar simetric, mai pronunțat în regiunea tenară și hipotenară, cu tendință netă spre leziuni teleangiectatice, care dispare la vitropresiune (caracter considerat de Degos de certitudine pentru LED).

-fisuri sangvinolente persistente pe tot decursul internării, la nivelul buzelor superioare și inferioare.

-modificări cutanate hiperkeratozice, cu elemente discoidale, cu localizare la nivelul articulațiilor genunchiului și cotului, care cedează în mare parte după instituirea tratamentului corticosteroid.

Aceste modificări cutaneo-mucoase pledează pentru lupus eritematos acut patent, fapt confirmat și de prezența intens pozitivă a celulelor lupice, de pozitivitatea testului latex Waaler-Roose și de valorile constant ridicate ale VSH-ului.

Cazul a fost internat la Spitalul Clinic Fundeni, unde prin determinarea factorului antinuclear, anticorpilor anticitoplasmatici, anticorpilor anti-fibre musculare, complexelor imune, etc., diagnosticul de trimitere a fost confirmat: lupus eritematos diseminat acut, formă clinică intricată cu artrită reumatoidă juvenilă, debut cu sindrom Wissler-Fanconi.

Cazul nr 2, prezentat pe scurt deoarece în filiera patogenetică a intervenit o afecțiune încă discutabilă ca încadrare în colagenoze, respectiv colita ulceroasă. Totuși punerea în discuție este utilă întrucât încadrarea în acest grup de afecțiuni în literatura pediatrică este o realitate, fenomenul de autoagresiune fiind similar cu cel din colagenoze [10]. Copilul H.F. de cinci ani, prezintă o afecțiune de debut cu febră de tip septic, cu durata de 5-6 săptămâni, cu apariția intercalată de rash cutanat de diferite intensități, artralgii, mialgii și care prin excluderea altor afecțiuni a fost etichetată ca boală Wissler-Fanconi, tratamentul cu corticostreroizi de durată medie fiind aparent benefic. Vindecarea s-a dovedit a fi aparentă, la două săptămâni de la externare copilul prezentând scaune numeroase, cu sânge, mucus și puroi, dureri abdominale puternice, cu tenesme. Presupunând o infecție bacteriană de tip enteroinvaziv s-a administrat un tratament cu dezinfectante intestinale, însă fără un rezultat convingător. După o evoluție de cinci săptămîni a fost internat la o clinică de pediatrie din Budapesta, unde pe baza rezultatului rectoscopiei și a altor examinări, a fost stabilit diagnosticul de colită ulceroasă, indicându-se tratament cu salazopirină, obținându-se vindecarea clinică. La un an de la externare debutează simptomatologia unei atropatii, cu modificări la nivelul articulațiilor mici interfalagiene, cuprinzând pe parcursul evoluției și articulațiile genunchiului și tibio-tarsiene. De această dată corticoterapia a fost ineficientă. După o evoluție de trei luni, la Spitalul Clinic Fundeni se precizează diagnosticul de artrită reumatoidă juvenilă, care a recționat foarte bine le tratament cu acid acetil salicilic „a la long”. Ca o curiozitate, menționez faptul că a fost vorba de cazul unui coleg al nostru, astăzi cu o sănătate perfectă.

\section{Concluzii}

1. Sindromul Wissler-Fanconi, conform practicii pediatrice și a datelor din literatură, poate fi considerat ca o anticameră a colagenozelor, cele două cazuri prezentate, la care în cadrul filierei patogenetice primum movens a fost subsepsis allergica, pledând în acest sens.

2. Evoluția sub forme intricate de colagenoze dovedește faptul că furnizează tablouri clinice obscure, greu descifrabile.

3. Intercalarea colitei ulceroase în veriga patogenetică vine în sprijinul tendințelor de încadrare a colitei ulceroase în cadrul afecțiunilor cu patogeneză autoagresivă, eventual al colagenozelor.

4. Lupusul eritematos diseminat acut este cea mai frecventă și cea mai gravă boală a țesutului conjunctiv întâlnită în practica pediatrică. 


\section{Referințe}

1. Desbois, JCL. Connectivites, în Perelman, R. Pediatrie practique, tome III, Paris, 1982,3073-3125.

2. Goldiș, G. Aspecte particulare clinice și terapeutice în colagenozele copilului, Congresul Național de Reumatologie, București, 1983,7-8.

3. Barnett, HL. Pediatrics, 15 th edition, New-Zork, A.C.C, 1974,508-514.

4. Schaller, JG. în Nelson. Textbook of Pediatrics, ediția a II-a, Philadelphia-London-Toronto, W.B.Saunders Co, 1979.

5. Gellis, SS, Kagan, BM. Current Pediatric Therapy, Philadelphia-London-Toronto, W.B.Saunders Co, 1976.

6. Green, M. Pediatric Diagnosis, Philadelphia-London-Toronto, W.B.Saunders Co, 1980.

7. Popescu, V. Lupus eritematos sistemic la copil, al III-lea Congres Național de Pediatrie, București, 1974.

8. Goodean, P, Herreman, G. Aspects clinique et evolution du lupus erithemateux, La revue du practicien, 1976; XXVI:929-945.

9. Arion, C, Popescu, V. Lupusul eritematos sistemic la copil, Pediatria, 1979;XXVI(1):19-34.

10. Lagercrantz, R, Hammerstrom, S, Perlmann, P. Autoimmunity in ulcerativ colitis, Acta Pediatrica Scandinavia 1967;111:167.

11. Degos, A. Trate du Dermatologie, Paris, 1963. 